\title{
Views on respiratory tract symptoms and antibiotics of Dutch general practitioners, practice staff and patients
}

\author{
Huug J. van Duijn ${ }^{\text {a,* }}$, Marijke M. Kuyvenhoven ${ }^{a}$, \\ François G. Schellevis $^{b}$, Theo J.M. Verheij ${ }^{a}$ \\ ${ }^{a}$ Julius Center for Health Sciences and Primary Care, University Medical Center (UMC), \\ Str. 6.131, P.O. Box 85060, 3508 AB Utrecht, the Netherlands \\ ${ }^{\mathrm{b}}$ Netherlands Institute for Health Services Research (NIVEL), 3500 BN Utrecht, the Netherlands
}

Received 8 December 2004; received in revised form 17 March 2005; accepted 25 March 2005

\begin{abstract}
Objectives: To explore views on respiratory tract symptoms (cough, sore throat and earache) and antibiotics of GPs, practice staff, and patients.

Methods: In a nationwide study, $181 \mathrm{GPs}, 204$ practice staff members and 1250 patients from 90 practices participated by answering 14 items relating to views on respiratory tract symptoms and antibiotics in a written questionnaire. Differences in means were compared.

Results: Patients more than GPs endorsed the seriousness of respiratory tract symptoms, the need to consult a GP, the need to prescribe antibiotics, and the ability of antibiotics to speed up recovery. GPs were more than patients convinced of the self-limiting character of respiratory tract symptoms and of the fact that antibiotics have side effects. Practice staff took a middle ground in most of these views. Conclusions: Differences between GPs, practice staff and patients must be taken into account when exploring patients' complaints and advising on treatment. Education and knowledge programmes for practice staff might be advocated.
\end{abstract}

(C) 2005 Elsevier Ireland Ltd. All rights reserved.

Keywords: Views; Respiratory tract symptoms; Antibiotics; General practitioners; Practice staff; Patients

\section{Introduction}

Respiratory tract symptoms such as cough, sore throat and earache are the most common reasons why patients consult a general practitioner (GP) [1]. Most of these symptoms are caused by viral infections, are self-limiting, and require only symptomatic over-the-counter medication to relieve the symptoms, while antibiotics shorten the duration of these symptoms only modestly, if at all [2-5]. Nevertheless, patients often seek medical advice, resulting in antibiotic prescription. Antimicrobial agents are used too often, even in the Netherlands [6-9], where antibiotic prescribing is low compared with other countries $[10,11]$. Negative consequences of this over-consumption are unnecessary costs, risk of side effects, unnecessary

\footnotetext{
* Corresponding author. Tel.: +31 71 4076429; fax: +31 714014638 .

E-mail address: hj@vduijn.nl (H.J. van Duijn).
}

utilisation of health services, and development of antimicrobial resistance $[8,12-14]$.

In general, patients' views differ from those of GPs [1519]. In case of respiratory tract symptoms, GPs tend to believe more than patients that these symptoms are self-limiting and not serious [17], while patients are not aware of the viral aetiology and overestimate effectiveness of antibiotics [20]. Patients' views and especially GPs' perception of patients' views towards medication seem to have a major influence on GPs' management of respiratory tract symptoms, especially regarding prescribing antibiotics [21-25]. Cockburn and Pit showed in an Australian study that patients who expected to receive medication were nearly three times more likely to actually receive medication, and GPs who perceived that patients expected to receive medication prescribed 10 times more than those who did not perceive [26].

Patients' views on seriousness, time-line, curability, and controllability have been shown to play a role in patients' 
coping behaviour relating to their illness, and therefore, in the doctor-patient relationship in patients with chronic diseases [27-30]. Probably, this is also the case in selflimiting illnesses; mutual misunderstanding and ignorance or disagreement about views on health and illness may negatively influence patient-doctor relationship, patient compliance regarding advice and treatment, and patient satisfaction [21,31,32]. Therefore, exploration of these dimensions of patient's views is needed for optimal patient education and treatment of patients with self-limiting illnesses as respiratory tract symptoms as well as chronic diseases.

Mutual misunderstanding and disagreement may also exist between patients and nurses or practice staff (paramedical qualified for nursing, administrative and receptionist tasks). In the Netherlands, practice staff have a growing task in intake and triage in general practice, similar to practice nurses and physician assistants in other countries [33,34]. Therefore, accordance in views between GPs and practice staff is important. Views of practice staff might influence self-medication and the threshold to consult a GP on the one hand, and patients' satisfaction and compliance on the other hand. However, there are no studies done so far to explore practice staff views on this topic.
This study aimed to explore views on respiratory tract symptoms (cough, sore throat and earache) and antibiotics of GPs, practice staff, and patients in a nation-wide study.

\section{Methods}

\subsection{GPs, practice staff, and patients}

The data used in this study originate from the Second Dutch National Survey of General Practice (DNSGP-2), which has been carried out by the Netherlands Institute for Health Services Research (NIVEL) in 2001 [35]. All GPs $(n=195)$ and practice staff members $(n=210)$ from 104 practices were invited to complete a questionnaire. In addition a random sample of all adult patients in DNSGP-2 practices was selected. Those adults who recently (i.e. within the last two weeks) suffered from cough, sore throat or earache (see flow chart) were invited to complete a questionnaire as well. Patients with a high score for psychiatric disturbance (GHQ-12-score of four items or more) were excluded because of participation in a study on mental illnesses [36].

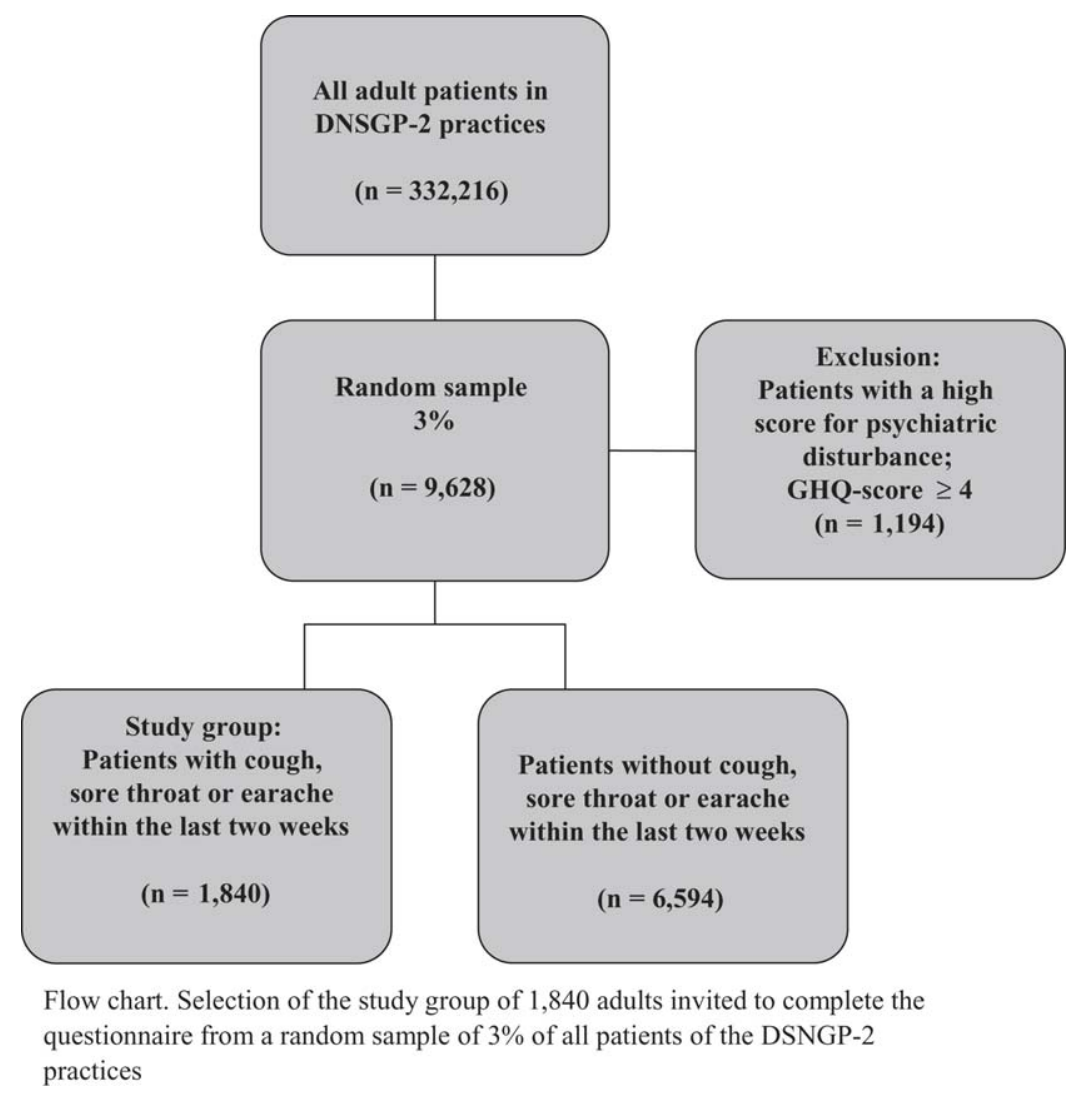




\subsection{Questionnaire}

The questionnaire completed by GPs, practice staff and patients contained 14 items used in earlier studies (see Appendix A) about views on respiratory tract symptoms and antibiotics, based on dimensions shown to be relevant in coping with chronic diseases [17,37]. These items referred to six views: perceived seriousness (three items), selflimiting properties (three items), need to consult a GP (three items), need to prescribe antibiotics (three items), effectiveness of antibiotics (one item), all in case of respiratory tract symptoms, and side effects of antibiotics (one item). The answers were rated on a Likert-type five-point-scale (rating from 1 , strongly disagree to 5 , strongly agree).

\subsection{Data processing and analysis}

Firstly, for each participant, means were calculated for those views containing three items combined with the intercorrelation between items (Cronbach's alpha). Next, means scores were calculated for GPs, practice staff and patients. These means were compared for all six views with a high score meaning a high endorsement and a low score a low endorsement of that view. Differences were tested by a Kruskal-Wallis-test (significance level: $p<.05$ ) [38]. Data analysis was performed with the Statistical Package for Social Sciences for Windows (SPPS 12.0.1).

\section{Results}

Completed questionnaires were returned by 181 GPs (response 93\%; Table 1) and 204 practice staff members (response 97\%). There were no differences between responding and non-responding GPs and practice staff regarding age, gender, and years of practice (Table 1). A complete questionnaire was returned by 1250 out of all 1840 adult patients recently suffering from cough, sore throat or earache $(68 \%)$. There were no differences between responders and non-responders regarding age, gender, type of insurance, chronic respiratory co-morbidity and diabetes mellitus or cardiovascular disease as co-morbidity, however, non-responding patients were more likely to smoke than responders (43\% versus $34 \%$; difference, $9 \%$; $95 \%$ CI, $5-$ $14 \%)$.

Patients differed from GPs in all views (Table 2). Patients considered respiratory tract symptoms more serious and less self-limiting and they thought there was more need for antibiotics in case of respiratory tract symptoms. They were more convinced about the effectiveness of antibiotics than GPs and estimated side effects of antibiotics as less important.

Practice staff differed in almost all views from both patients and GPs. They adopted a middle ground between patients and GPs in views concerning seriousness, selflimiting character of respiratory tract symptoms, need to prescribe antibiotics, and effectiveness of antibiotics. Surprisingly, practice staff reported an even greater need to consult a GP than both patients and GPs. Practice staff were as concerned about side effects of antibiotics as GPs.

\section{Discussion and conclusion}

\subsection{Conclusion}

In this nation-wide study in the Netherlands, patients endorsed more than GPs the seriousness of respiratory tract symptoms, the need to consult a GP for these symptoms, the need to prescribe antibiotics for them, and the ability of antibiotics to speed up recovery. GPs were more convinced than patients of the self-limiting character of respiratory tract symptoms and of the fact that antibiotics have side effects. Practice staff took a middle ground in most of these views.

\subsection{Strength and limitations of the study}

The participation of GPs, practice staff, and patients was high as compared to other surveys. There were no differences between participants and non-participants, except that, for patients, less participants than nonparticipants smoked. Because smoking behaviour was not correlated with patients' views, we assume that this difference did not bias our results.

Table 1

Demographic characteristics of general practitioners (GPs), practice staff and patients (study groups and responders)

\begin{tabular}{|c|c|c|c|c|c|c|}
\hline & \multicolumn{2}{|l|}{ GPs } & \multicolumn{2}{|l|}{ Practice staff } & \multicolumn{2}{|l|}{ Patients } \\
\hline & $\begin{array}{l}\text { Study group } \\
(n=195)\end{array}$ & $\begin{array}{l}\text { Responders } \\
(n=181)\end{array}$ & $\begin{array}{l}\text { Study group } \\
(n=210)\end{array}$ & $\begin{array}{l}\text { Responders } \\
(n=204)\end{array}$ & $\begin{array}{l}\text { Study group } \\
(n=1840)\end{array}$ & $\begin{array}{l}\text { Responders } \\
(n=1250)\end{array}$ \\
\hline Age (mean and S.D.) & $46.7(6.6)$ & $47.1(6.4)$ & $37.9(9.9)$ & $37.9(10.0)$ & $47.3(17.8)$ & $47.1(17.2)$ \\
\hline Gender (\%female) & 27 & 26 & 100 & 100 & 58 & 58 \\
\hline Practising years (mean and S.D.) & $17.7(8.7)$ & $18.2(8.7)$ & $10.6(7.3)$ & $10.6(7.4)$ & & \\
\hline Smokers $(\%)$ & & & & & 37 & 34 \\
\hline Health insurance (\%) & & & & & 67 & 66 \\
\hline Chronic respiratory co-morbidity (\%) & & & & & 13 & 13 \\
\hline DM and/or cardiovascular disease (\%) & & & & & 11 & 10 \\
\hline
\end{tabular}


Table 2

Views of general practitioners (GPs), practice staff, and patients about respiratory tract symptoms and antibiotics (AB) (Cronbach's $\alpha$; mean and S.D.) ${ }^{\mathrm{a}}$

\begin{tabular}{|c|c|c|c|c|c|c|}
\hline \multirow[t]{2}{*}{ Views on respiratory tract symptoms and $\mathrm{AB}$} & \multicolumn{2}{|l|}{ GPs $(n=181)$} & \multicolumn{2}{|c|}{ Practice staff $(n=204)$} & \multicolumn{2}{|c|}{ Patients $(n=1250)$} \\
\hline & Mean (S.D.) & $\alpha$ & Mean (S.D.) & $\alpha$ & Mean (S.D.) & $\alpha$ \\
\hline Seriousness $^{\mathrm{b}}$ & $2.0(0.8)$ & .85 & $3.0(1.0)$ & .93 & $3.2(1.0)$ & .78 \\
\hline Self-limiting character ${ }^{\mathrm{b}}$ & $4.3(0.6)$ & .59 & $3.9(0.8)$ & .64 & $3.3(0.7)$ & .62 \\
\hline Need to consult a GP $\mathrm{GP}^{\mathrm{b}}$ & $3.6(0.8)$ & .52 & $4.2(0.7)$ & .48 & $3.8(0.6)$ & .63 \\
\hline Need to prescribe $A B^{b}$ & $1.7(0.7)$ & .86 & $2.5(1.0)$ & .89 & $3.1(1.0)$ & .82 \\
\hline Effectiveness of $\mathrm{AB}^{\mathrm{b}}$ & $1.9(0.9)$ & & $2.4(1.2)$ & & $3.6(0.9)$ & \\
\hline Side effects of $\mathrm{AB}^{\mathrm{c}}$ & $3.8(1.0)$ & & $3.8(1.0)$ & & $3.1(1.0)$ & \\
\hline
\end{tabular}

a The answers were ranged as follows: 1, totally disagree to 5 , totally agree.

b Difference between GPs and practice staff, GPs and patients, and practice staff and patients (Kruskal-Wallis-test; $p<.01)$.

${ }^{\mathrm{c}}$ Difference between GPs and patients, and practice staff and patients (Kruskal-Wallis-test; $p<.01$ ), but not between GPs and practice staff $(p=.25)$.

We included only patients who had recently cough, sore throat or earache, because these are the patients who are found in GP practices and, as a result, the practice implications would be better grounded. Patients with a high risk of psychiatric disturbance were excluded. There are indications that these patients perceive symptoms more serious and perceive greater need to consult a GP than patients with a low risk [39]. So, the differences between patients on the one hand, and GPs and practice staff on the other hand, we assessed in our study might be slightly underestimated.

\subsection{Comparison with the existing literature}

In an earlier study among small groups of patients and GPs, we showed corresponding differences in views between GPs and patients relating (acute) respiratory tract symptoms and antibiotics [17]. Our findings agree with those of Varonen and Saino, who also reported also that patients had less confidence in natural course of sinusitis than physicians [18].

Our findings are also in line with studies in which nurses in- and outside hospitals have been found to be in a middle position between physicians' and patients' views on health and illness [16,40].

Patients' views in this study are similar with those measured in Dutch respondents in an international study carried out among patients in the Netherlands, UK and Belgium, countries with a low, moderate, and high outpatient antibiotic use [41]. In that study, we found that Belgian responders perceived a higher need to consult a
GP in case of respiratory tract symptoms, and perceived these symptoms as more serious and less self-limiting than responders in UK and the Netherlands. However, they did not differ in views on effectiveness and side effects of antibiotics. Therefore, we think that our findings are also relevant for other settings outside the Netherlands.

\subsection{Practice implications}

Differences in views between patients with recent experience with respiratory tract symptoms and GPs underline the importance to explore patients' views about respiratory tract symptoms and antibiotics in individual cases to avoid misperception, to make explanation more effective and to improve shared decision making [42-44] and so decreasing over-prescribing of antibiotics [32].

Practice staff was taking a middle ground between GPs and patients in most dimensions, and almost all of their views differed significantly from GPs. Intake and triage by paramedic personnel (practice staff, practice nurses, physician assistants) is increasingly important in general practice $[33,34]$. More agreement between GPs' and practice staff views is, therefore, desirable in order to ensure uniform disease management within practices. Quality assurance programs should target consensus and mutual understanding between the different health professionals in primary care concerning assessment of respiratory symptoms and indications for antibiotic treatment. 
Appendix A. Overview of items used in the questionnaire according to views on respiratory tract symptoms and antibiotics*

\begin{tabular}{|c|c|c|c|c|c|}
\hline & $\begin{array}{l}\begin{array}{l}\text { Strongly } \\
\text { disagree }\end{array} \\
\end{array}$ & Disagree & \begin{tabular}{|l|} 
Neither \\
agree nor \\
disagree
\end{tabular} & Agree & $\begin{array}{l}\text { Strongly } \\
\text { agree }\end{array}$ \\
\hline \multicolumn{6}{|l|}{ Perceived seriousness } \\
\hline \multicolumn{6}{|c|}{$\begin{array}{l}\text { A cough, together with a raised } \\
\text { temperature suggests a serious infection }\end{array}$} \\
\hline \multicolumn{6}{|c|}{$\begin{array}{l}\text { A sore throat, together with a raised } \\
\text { temperature suggests a serious infection }\end{array}$} \\
\hline \multicolumn{6}{|l|}{$\begin{array}{l}\text { A child with a raised temperature and } \\
\text { earache suggests a serious infection }\end{array}$} \\
\hline \multicolumn{6}{|l|}{ Perceived self-limiting character } \\
\hline \multicolumn{6}{|l|}{$\begin{array}{l}\text { Cough almost always gets better } \\
\text { without treatment within two weeks }\end{array}$} \\
\hline \multicolumn{6}{|l|}{$\begin{array}{l}\text { Sore throat almost always gets better } \\
\text { without treatment within one week }\end{array}$} \\
\hline \multicolumn{6}{|l|}{$\begin{array}{l}\text { Earache almost always gets better } \\
\text { without treatment within two days }\end{array}$} \\
\hline \multicolumn{6}{|l|}{ Need to consult a GP } \\
\hline \multicolumn{6}{|l|}{$\begin{array}{l}\text { If a cough lasts longer than two } \\
\text { weeks, it is advisable to see a doctor }\end{array}$} \\
\hline \multicolumn{6}{|l|}{$\begin{array}{l}\text { If sore throat lasts longer than one } \\
\text { week, it is advisable to see a doctor }\end{array}$} \\
\hline \multicolumn{6}{|l|}{$\begin{array}{l}\text { If earache lasts longer than two days, it } \\
\text { is advisable to see a doctor }\end{array}$} \\
\hline \multicolumn{6}{|l|}{ Need of antibiotics } \\
\hline \multicolumn{6}{|l|}{$\begin{array}{l}\text { You need treatment with antibiotics if } \\
\text { you have both a cough and a raised } \\
\text { temperature }\end{array}$} \\
\hline \multicolumn{6}{|l|}{$\begin{array}{l}\text { You need treatment with antibiotics if } \\
\text { you have both a sore throat and a raised } \\
\text { temperature }\end{array}$} \\
\hline \multicolumn{6}{|c|}{$\begin{array}{l}\text { A child needs treatment with antibiotics } \\
\text { if it has both earache and a raised } \\
\text { temperature }\end{array}$} \\
\hline \multicolumn{6}{|l|}{ Effectiveness of antibiotics } \\
\hline \multicolumn{6}{|l|}{$\begin{array}{l}\text { Antibiotics speed recovery from } \\
\text { symptoms as cough, sore throat and } \\
\text { earache }\end{array}$} \\
\hline \multicolumn{6}{|l|}{ Side effects of antibiotics } \\
\hline Antibiotics have many side effects & & & & & \\
\hline
\end{tabular}

* items were included in the questionnaire in a random order

\section{References}

[1] Bauman KA. The family physician's reasonable approach to upper respiratory tract infection care for this century. Arch Fam Med 2000;9:596-600.

[2] Arroll B, Kenealy T. Antibiotics for the common cold. Cochrane Database Syst Rev. CD000247 [review, 2002 update].

[3] Arroll B, Kenealy T. Antibiotics for acute bronchitis. Brit Med J 2001;322:939-40.

[4] Del Mar CB, Glasziou PP, Spinks AB. Antibiotics for sore throat. Cochrane Database Syst Rev. CD000023 [review, 2000 update].

[5] Glasziou PP, Hayem M, Del Mar CB. Antibiotics for acute otitis media in children. Cochrane Database Syst Rev. CD000219 [review, 2000 update].

[6] Butler Chr C, Rollnick S, Pill R. Understanding the culture of prescribing: qualitative study of GP's and patients' perceptions of antibiotics for sore throats. Brit Med J 1998;317:637-42.
[7] Gonzales R, Steiner JF, Sande MA. Antibiotic prescribing for adults with colds, upper respiratory tract infections, and bronchitis by ambulatory care physicians. JAMA-J Am Med Assoc 1997;278:901-4.

[8] Kuyvenhoven MM, Van Balen FAM, Verheij TJM. Outpatient antibiotic from 1992 till 2001 in the Netherlands. J Am Culture 2003;52:675-8.

[9] Nyquist AC, Gonzales R, Steiner JF, Sande MA. Antibiotic prescribing for children with colds, upper respiratory tract infections, and bronchitis. JAMA-J Am Med Assoc 1998;279:875-7.

[10] Goossens H, Ferech M, Vander Stichele R, Elseviers M. Outpatient antibiotic use in Europe and association with resistance: a crossnational database study. Lancet 2004;365:579-87.

[11] Froom J, Culpepper L, Jacobs M, DeMelker RA, Green LA, van Buchem L, Grob P, Heeren T. Antimicrobials for acute otitis media? A review from the international primary care network. Brit Med J 1997;315:98-102. 
[12] Bronzwaer SLAM, Cars O, Buchholz U, Mölstad S, Goettsch W, Veldhuijzen IK, Kool JL, Sprenger MJW, Degener JE. A European study on the relationship between antimicrobial use and antimicrobial resistance. Emerg Infect Dis 2002;8:278-82.

[13] Coughlin CM, Nelson M, Merchant S, Gondek K. Costs of broadspectrum antibiotic use for acute sinusitis, chronic bronchitis, and pneumonia in a managed care population. Manag Care Interface 2003;16:34-40, 55.

[14] Wise R, Hart T, Cars O, Streulens M, Helmuth R, Huovinen P, Sprenger M. Antimicrobial resistance is a major threat to public health. Brit Med J 1998;317:609-10.

[15] Rotthwell PM, McDowell Z, Wong CK, Dorman PJ. Doctors and patients don't agree: cross sectional study of patients' and doctors' perceptions and assessments of disability in multiple sclerosis. Brit Med J 1997;314:1580-3.

[16] Sarrell M, Cohen HA, Kahan E. Physicians', nurses, and parents' attitudes to and knowledge about fever in early childhood. Patient Educ Couns 2002;46:61-5.

[17] Van Duijn H, Kuyvenhoven M, Welschen I, Den Ouden H, Slootweg A, Verheij T. Patients' and doctors' views on respiratory tract symptoms. Scand J Prim Health 2002;20:201-2.

[18] Varonen H, Sainio S. Patients' and physicians' views on the management of acute maxillary sinusitis. Scand J Prim Health 2004;22:22-6.

[19] Landy J, Stein JD, Brown MM, Brown GC, Sharma S. Patient, community and clinician perceptions of the quality of life associated with diabetes mellitus. Med Sci Monit 2002;8:543-8.

[20] Wilson AA, Crane LA, Barrett PH, Gonzales R. Public beliefs and use of antibiotics for respiratory illness. J Gen Intern Med 1999;14:65862 .

[21] Butler Chr C, Rollnick S, Kinnersley P, Jones A, Stott N. Reducing antibiotics for respiratory tract symptoms in primary care: consolidating 'why' and considering 'how'. Brit J Gen Pract 1998;48:1865-70.

[22] Davey P, Pagliari C, Hayes A. The patient's role in the spread and control of bacterial resistance to antibiotics. Clin Microbiol Infect 2002;8(Suppl. 2):43-68.

[23] Macfarlane J, Holmes W, Macfarlane R, Britten N. Influence of patients expectations on antibiotic management of acute lower respiratory tract illness in general practice: questionnaire study. Brit Med J 1997;315:1211-4.

[24] Welschen I, Kuyvenhoven MM, Hoes A, Verheij TJM. Antibiotics for acute respiratory tract symptoms: patients' expectations GPs' management and patients' satisfaction. Fam Pract 2004;21:234-7.

[25] Scott JG, Cohen D, DiCicco-Bloom B, Orzano J, Jaén CR, Crabtree BF. Antibiotic use in acute respiratory infections and the ways patients pressure physicians for a prescription. J Fam Practice 2001;50:853-8.

[26] Cockburn J, Pit S. Prescribing behaviour in clinical practice: patients' expectations and doctors' perceptions of patients' expectations-a questionnaire study. Brit Med J 1997;315:520-3.

[27] Moss-Morris R, Chalder T. Illness perceptions and levels of disability in patients with chronic fatigue syndrome and rheumatoid arthritis. J Psychosom Res 2003;55:305-8.

[28] Rutter CL, Rutter DR. Illness representation, coping and outcome in irritable bowel syndrome (IBS). Brit J Health Psych 2002;7:377-91.
[29] Scharloo M, Kaptein AA, Weinman J, Bergman W, Vermeer BJ, Rooijmans HGM. Patients' illness perceptions and coping as predictors of functional status in psoriasis: a 1-year follow-up. Brit $\mathrm{J}$ Dermatol 2000;142:899-907.

[30] Theunissen NC, De Ridder DT, Bensing JM, Rutten GE. Manipulation of patient-provider interaction: discussing illness representations or action plans concerning adherence. Patient Educ Couns 2003;51:24758.

[31] Barry CA, Bradley CP, Britten N, Stevenson FA, Barber N. Patients' unvoiced agendas in general practice consultations: qualitative study. Brit Med J 2000;320:1246-50.

[32] Welschen I, Kuyvenhoven MM, Hoes AW, Verheij TJM. Effectiveness of a multiple intervention to reduce antibiotic prescribing for respiratory tract symptoms in primary care: randomised controlled trial. Brit Med J 2004;329:431-3.

[33] Gallagher M, Huddart T, Henderson B. Telephone triage of acute illness by a practice nurse in general practice: outcomes of care. Brit J Gen Pract 1998;48:41-5.

[34] Richards DA, Meakins J, Godfrey L, Tawfik J, Dutton E. Survey of the impact of nurse telephone triage on general practitioner activity. Brit J Gen Pract 2004;54:207-10.

[35] Westert GP, Schellevis FG, De Bakker DH, Groenewegen PP, Bensing JM, Van der Zee J. Monitoring health inequalities through general practice: the Second Dutch National Survey of General Practice. Eur J Public Health 2005; 15:59-63.

[36] Hoeymans N, Garssen AA, Westert GP, Verhaak PFM. Measuring mental health of the Dutch population: a comparison of the GHQ-12 and the MHI-5. Health Qual Life Outcomes 2004;2:23-8.

[37] Van Duijn HJ, Kuyvenhoven MM, Tudor Jones R, Butler CC, Coenen S, Van Royen P. Patients' views on respiratory tract symptoms and antibiotics. Brit J Gen Pract 2003;53:491-2.

[38] Siegel S, Castellan NJ. Nonparametric statistics for the behavioral sciences, 2nd ed. New York: McGraw-Hill, 1988.

[39] Bellon JA, Delgado A, Luna JD, Lardelli P. Psychosocial and health belief variables associated with frequent attendance in primary care. Psychol Med 1999;29:1347-57.

[40] Caldwell TM, Jorm AF. Mental health nurses' beliefs about likely outcomes for people with schizophrenia or depression: a comparison with the public and other healthcare professionals. Aust NZ Ment Health Nurs 2001;10:42-54.

[41] Van Duijn HJ, Kuyvenhoven MM, Butler CC, Coenen S, Verheij TJM. Variation in outpatient antibiotic use in three European countries: exploration of possible determinants. Eur J Gen Pract 2005 [in press].

[42] Edwards A, Evans R, Elwyn G. Manufactured but not imported: new directions for research in shared decision making support and skills. Patient Educ Couns 2003;50:33-8.

[43] Elwyn G, Gwyn R, Edwards A, Grol R. Is 'shared decision-making' feasible in consultations for upper respiratory tract infections? Assessing the influence of antibiotic expectations using discourse analysis. Health Expect 1999;2:105-17.

[44] Epstein RM, Alper BS, Quill TE. Communicating evidence for participatory decision making. JAMA-J Am Med Assoc 2004;291: 2359-66. 